\title{
Analysis of Latvian Households' Potential Participation in the Energy Market as Prosumers
}

\author{
Kristina Lebedeva ${ }^{1, *}$, Andris Krumins ${ }^{2}$, Antra Tamane ${ }^{1}$ and Egils Dzelzitis ${ }^{1}$ \\ 1 Department of Heat Engineering and Technology, Riga Technical University, LV-1048 Riga, Latvia; \\ antra@intellify.lv (A.T.); egils.dzelzitis@rtu.lv (E.D.) \\ 2 Lafivents Ltd., LV-1004 Riga, Latvia; andrisk@lafivents.lv \\ * Correspondence: kristina.lebedeva@rtu.lv
}

Citation: Lebedeva, K.; Krumins, A.; Tamane, A.; Dzelzitis, E. Analysis of Latvian Households' Potential Participation in the Energy Market as Prosumers. Clean Technol. 2021, 3 437-449. https://doi.org/10.3390/ cleantechnol3020025

Academic Editor: Patricia Luis

Received: 3 March 2021

Accepted: 2 April 2021

Published: 17 May 2021

Publisher's Note: MDPI stays neutra with regard to jurisdictional claims in published maps and institutional affiliations.

Copyright: (c) 2021 by the authors. Licensee MDPI, Basel, Switzerland. This article is an open access article distributed under the terms and conditions of the Creative Commons Attribution (CC BY) license (https:// creativecommons.org/licenses/by/ $4.0 /)$
Abstract: The European Union sets targets for the extensive use of renewable energy. Meanwhile, the energy production network is changing and transferring from the classic "producer to consumer" scheme to new operation models, where a small consumer with local renewable energy systems becomes a producer-prosumer, an active energy consumer who is also an energy producer. This study evaluated a potential of Latvian households' participation in the energy market as prosumers. The analysis was based on an informal prospective extrapolation data evaluation method, based on real historical data from the Central Statistical Bureau of Latvia, annual reports of distribution and transmission system operators, assessments, and the conclusions of relevant experts. In addition, the real performance of a photovoltaic (PV) system was evaluated to get information on the whole year's energy balance, and to compare it with seasonal electricity price fluctuation. The Latvian electricity transmission system is able to accept about $800 \mathrm{MW}$ of additional new renewable energy source (RES) capacity, so there is a great potential for prosumers. The biggest obstacle for a household's involvement in the energy market is the lack of support mechanisms and relatively high cost of RES technologies. The results show that with the current dynamics of new microgenerator connections, Latvia will achieve the set goals regarding the involvement of prosumers in the achievement of RES goals only in the next century. In order to attract the public to energy production, the concept of energy community needs to be defined in Latvian legislation, a balanced peer trading mechanism needs to be developed for various RES self-consumption groups willing to sell surplus electricity, and tax policy conditions need to be reviewed for electricity transactions outside the NET (payment system), in order to fully ensure the rights of prosumers.

Keywords: household energy consumption; renewable energy source (RES); microgenerator; NET payment system; prosumer; energy market

\section{Introduction}

More than $80 \%$ of global energy production is based on traditional fossil fuels: coal, oil and natural gas [1]. One of the most significant air polluters are fallouts resulting from the burning of fossil fuel [2]. Over the last decade, natural gas consumption in Latvia has remained fairly stable; however, its consumption may decrease in the near future due to the installation of renewable energy systems, which increase the sustainability of the systems [3]. Today, due to global environmental challenges like climate change and increasing greenhouse gas emissions, energy production processes have to follow a "decarbonization process". Sustainable energy transition means not only the transition from fossil to renewable energy sources, but also the improvement of energy efficiency in the energy production process [4,5]. In particular, the articles of the Renewable Energy Directive and the Electricity Market Directive send a clear message about the necessity of strengthening the use of self-consumption in decentralized generation in each European Union (EU) member state. The development of distributed energy resources-in particular, 
renewable energy sources and multi-generational systems-are promising opportunities that could change the concept of energy production in the future from large centralized power plants to local and distributed [6].

In our study, we analyzed policy documents that can influence the successful implementation of households as active consumers in the energy market. Both EU and Latvian political documents, with a definite emphasis on Latvian conditions, were considered.

Recent decades have seen a strong trend towards the integration of renewable distribution generation systems into the grid, and advanced management strategies have been developed to ensure reliable, flexible, economical, and sustainable operation [7]. As the share of renewable energy in the EU increases (more than doubled between $2004(9.6 \%)$ and $2019(19.7 \%))$ [8], the share of energy cooperatives (active consumers as active participants in the energy system) active in the energy transition has risen too, which confirms the important role of energy cooperatives in the transition to renewable energy systems in each EU member state [9]. With more than 500 million inhabitants, around 216 million households, and around 20 million small businesses, it is clear that there is a huge potential for active citizens in the EU's energy or consumer circles [10]. Energy-efficient public-private partnership schemes, as part of the 7th Framework Programme and Horizon 2020, aim to develop affordable technologies and solutions for building and district scales [11]. The role of "citizen energy" in the energy perspective in the EU energy transition process could be remarkable: over 112 million energy citizens could provide up to 19\% of Europe's electricity demand by 2030; by 2050 this could increase to up to $45 \%$ of total electricity demand, including collective projects up to $37 \%$ [10]. It is widely acknowledged that peer-to-peer energy trading will provide a solid basis on which to strengthen the rapid, convenient, and competitive use of energy by maximizing the reserve capacity of energy prosumers [12]. Prosumers are individuals, groups of people, households, or farms that can function in an organized way-for example, through associations, foundations, or cooperatives-that are both producers and consumers of energy, produced in small installations in courtyards or in residential or commercial buildings (for example, miniature wind turbines, photovoltaic (PV) panels, solar panels, and heat pumps) [13]. The EU has no specific legislation on prosumers, self-production, or self-consumption, and there is no general definition of prosumers. However, the Energy Efficiency Directive, the Renewable Energy Directive, and the State Aid Guidelines contain provisions for small electricity producers. The EU Parliament called for a common definition of prosumers in the EU and for new energy legislation, with measures to stimulate investment in its own production capacity [14]. The transition to a low-carbon-based renewable energy system creates a new role for citizens, from passive energy consumers to active energy people-the so-called renewable energy (RE) prosumers in each EU member state [15]. For the successful establishment of prosumer communities, each prosumer must be considered in the community's load balance as a microgrid, while minimizing the total cost of energy received from the network during the relevant period of operation [16]. The power grid transfers energy from remote areas (where power plants are located) over long distances to residential consumption centers [17]. Generally, the best decision is to have a RE system in the center of small communities (1-5 houses), in clusters to provide all communities with electricity with minimal energy losses and voltage drops [18].

The long-term objective of Latvia's National Energy and Climate plan (NECP) 2021-2030 [19] (one of the main energy planning documents in Latvia) is to promote a climate-neutral economy by improving energy security and the well-being of society in a sustainable, competitive, cost-effective, secure, and market-based manner. To achieve the objectives of the plan, the areas of action were identified among the defined actions. The present study focuses on the following two:

- Promote the use of technologies with negative emissions in electricity generation;

- Promote economically viable energy production and self-energy consumption.

Despite the fact that the introduction of energy efficiency measures in Latvia is widely reported, there is still a lack of public information and educational measures to promote 
renewable energy sources [19]. Results of one study [20] show that renewable energy business models are highly dependent on different national, contextual environments, such as policy frameworks, transaction costs, the electricity market, and the construction industry and consumer factors.

Considering that important aspects for the development of prosumers (in Europe, as well as in Latvia), such as the development of new technologies, the choice of appropriate organizational and financial models, and political and financial decisions, are still far from being able to implement the innovation approach, an analysis of possible participation of households in the energy market can contribute to involving citizens in energy production and self-consumption, which will promote the efficiency and sustainability of the energy market and the functioning of the energy system.

The movement of prosumers in Latvia is at an early stage of development. However, there are various initiatives, including small enterprises, municipal, and individual citizens that incorporate the features of energy prosumers or renewable energy source (RES) projects. Various RES are used for electricity generation in the residential sector, such as solar and wind energy. Solar energy is the most common form of renewable energy, due to its many benefits: it is available in many locations, has low operating costs, and can be adapted to small decentralized systems [21]. At the same time, the use and growth of PV systems makes it possible to increase the electrification of transportation: powering electric vehicles with electricity supplied by PV panels is efficient and profitable [22]. Solar energy can play a major role in reducing greenhouse gas emissions from the electricity sector [23]. PV panels, solar collectors, and heat pumps (HP) are the most popular equipment for the household energy generation in Latvia. HPs are environmentally friendly technology, using renewable energy that does not produce exhaust gases while heating any space, especially if the compressor of HP is driven by green electricity [24]. The combined system has a higher coefficient of performance, and the comparison of the data derived from electricity demand shows an energy savings of $40 \%$; this can also be expressed as a $2.08\left(\mathrm{tCO}_{2} /\right.$ year $)$ carbon footprint reduction [25].

This article aims to conduct an analysis of Latvian households' potential participation in the energy market as prosumers, providing an overview and analysis of the technological, financial, and motivational obstacles and aspects that exist in the Latvian energy policy. Our research also includes a detailed analysis of the current situation of public involvement in electricity production in Latvia.

The most significant sources of electricity generation in Latvia are the Riga natural gas combined heat and power plants TEC-1 and TEC-2, with a total installed electrical capacity of $976 \mathrm{MW}$ in 2019, and the Daugava cascade hydro power plants (HPPs) with an installed capacity of $1558 \mathrm{MW}$ [26]. The total installed electrical capacity in Latvia was 2915 MW in 2019; other RES power plants, excluding Daugava HPP, make up just 9\% (wind, small hydropower, solar power plants, and biomass and biogas cogeneration plants) [27]. The Daugava HPPs have a high proportion of installed capacity, but considering their fluctuating generation, which is significantly dependent on climatic conditions, natural gas cogeneration plants still play an important role in Latvia's energy supply. In 2017, under favorable conditions for the operation of HPPs, the local generation covered Latvia's electricity consumption at the amount of $101 \%$, while in 2019 , under significantly less favorable conditions, only at the amount of $84.7 \%$ [28]. It follows from the above that electricity production in Latvia is characterized by low diversification of energy sources, which significantly affects self-sufficiency in energy dependence on imported fossil sources [19].

In March 2020, 573 microgenerator connections (up to $11.1 \mathrm{~kW}$ ) were registered in Latvia. Their total installed electrical capacity was $3.4 \mathrm{MW}$, which is a small part $(\sim 0.1 \%)$ of the total installed electrical capacity in Latvia. It is calculated using permits issued in accordance with Cabinet Regulation No. 883 of 11 August 2009, "Regulations on Permits for Increasing Electricity Generation Capacities or Introduction of New Generation Facilities" (as of 30 June 2020). 
Ninety-eight households of these 573 connections sell stored energy to energy traders for commercial purposes: the electricity trader buys electricity at the price at which he would be able to sell it on the market, covering his own costs, but without distribution and transmission service costs or the mandatory procurement component (OIK), and the electricity producer bilaterally agrees on the terms of cooperation. According to the data of the Ministry of Economics on the connections of microgenerators, the absolute majority of them generate energy using renewable energy resources ( $98 \%$ is solar energy).

At the same time, there are households and legal entities that install higher capacity equipment for their own energy production, and there are currently no incentives available for legal entities [17]. Up to June 2020, the Ministry of Economics (ME) had issued 282 permits to increase electricity generation capacity or introduce new generation facilities that do not meet the requirements for microgenerator connections [24]. According to the information of the ME on issued permits, $46 \%$ of them use solar energy and $30 \%$ use wind energy to generate electricity; the rest also use RES hydropower or biomass cogeneration plants. Thirty-seven percent of electricity is produced for their own consumption, and only $4 \%$ of the permits have been for households and other legal entities.

If a permit to increase electricity generation capacity or to introduce new generation facilities is received, it is not guaranteed that the rights to sell electricity produced from renewable energy sources or to sell electricity produced in cogeneration within the framework of mandatory procurement (OIK) will be acquired [26].

Latvia's National Energy and Climate Plan 2021-2030 (Order of the Cabinet of Ministers No. 46 of 4 February 2020), Article 4.8, described and adopted recommendations for the improvement of legislation by 2030 for successful public involvement in energy production.

Analyzing this plan [17], it was concluded that there is only one support mechanism in Latvia that can increase public involvement in the electricity market as a generating consumer-NET payment system. In order to attract more households to participate in the energy market as productive consumers-prosumers, major changes in Latvian legislation are needed.

The NET system was introduced by Article 30 of the Electricity Market Law. It has been valid since 1 January 2014. The NET system stipulates that households that produce electricity for their own needs and transfer the surplus to the grid can use the NET payment system, which allows them to accumulate generated units of electricity and use it during the year, paying only for the mandatory purchase, distribution, and transmission components. In March 2020, the NET system was used by 519 household consumers, and their total installed capacity was $2.8 \mathrm{MW}$ [26].

Other energy producers participate in the NET payment system, where the surplus of produced solar energy is transferred to a common grid, used by the grid as storage, and recovered when needed by paying distribution and transmission fees, as well as the OIK. This payment accounted for about $40 \%$ of the total electricity price. On 7 April 2020, the Cabinet of Ministers approved amendments to regulation number 50, "Regulations Regarding the Trade and Use of Electricity", simplifying the procedure for application of the NET payment system for electricity (NET system). From 1 April 2020, households no longer have to pay the variable part of the OIK for electricity transmitted and returned to the grid.

Amendments to the regulations, which will further affect the users of the NET electricity payment system, provide that excess electricity that is produced and not consumed can be "accumulated". In this case, the electricity "accumulator" is an electricity distribution system, which is supervised by Joint Stock Company (JSC) "Sadales Tīkls". For the end user, this manifests itself as follows: unused electricity produced from solar panels during the day is returned to the network, which is accounted for by JSC "Sadales Tīkls". The amount of electricity that can be stored in the electricity "accumulator" during the month is fixed. If the amount of electricity consumed for several months is less than the amount of electricity produced, accumulated energy will be added up. The network is like a battery 
with an accumulation period from 1 April to 31 March of the following year. On 1 April, a new accumulation period begins, deleting the unused amount of $\mathrm{kWh}$ of the previous year.

It is clear from the national energy regulatory documents that the NET payment system was introduced as a state support mechanism to promote the production of electricity from renewable energy sources in general, as well as to promote the involvement of the population in the production of renewable energy.

Our research is a part of a project aiming to balance energy demand by implementing a high-level management system for building management, energy storage, and energy exchange based on energy market dynamics and the short-term manipulation of parameters in climate control systems.

The article is structured as follows: in Section 2, we include a description of the method for collecting and processing information, as well as the possibilities of RES (wind and PV); the use for energy production in Latvian households and also considered, using an example of a real installation, for further possible PV users' participation in the energy market as prosumers in Latvian climatic conditions. In Section 3, we identified the theoretical justification of the consumer introduction into the Latvian electricity market and conducted an evaluation of real PV system electricity production versus dynamic electricity price. In Section 4, we provided the results of our analysis, and made some recommendations for changing the conditions of tax policy for RE prosumers.

\section{Materials and Methods}

Research based on data from the Central Statistical Bureau (CSB) of Latvia, energy balances [29], annual reports of distribution system operator JSC "Sadales Tīkls" (ST), transmission system operator JSC "Augstsprieguma tikls" (AST) [30,31], the Ministry of Environmental Protection and Regional Development [32], and the Ministry of Economics $[33,34]$, as well as on data from Latvian legislation acts $[19,35,36]$ and publications prepared by international organizations the European Economic and Social Committee, International Renewable Energy Agency, CE Delft, European Parliament [5-14], and some research works and publication $[1,6,9,11,15,22,37]$, were overviewed and analyzed.

The analysis was based on an informal prospective extrapolation data evaluation method. After collecting data on households and the types of RES used by them for energy production (using the above sources-real historical data from the CSB, ST, and AST, as well as comparative indicators prepared based on experts' assessments), conclusions were drawn about the past and present sustainable trends in the development and increase of households using RES. As the data are very limited and based on publicly available information, this forecasting method has been applied.

Taking into account the current situation in Latvia regarding supporting the participation of prosumers in the energy market, various renewable energy sources for electricity generation in households will be considered. Following the analysis of Latvian energy-producing households, wind turbines and solar panels, which are the most popular equipment for generating electricity at home for final consumption, will be discussed.

\subsection{Possibilities of RES (Wind and PV) Use for Energy Production in Latvian Households}

In Latvia, wind generators with a total installed capacity of 78 MW (about 150 wind turbines with different capacities in 2019) produced 152 GWh of electricity [29]. According to the data of the Ministry of Economics, in 2019, 39 companies with 64.695 MW installed capacity had permits to increase electricity generation capacity or for new generation facilities, which received the right to sell electricity produced from renewable energy sources within the framework of mandatory procurement (OIK). Permits for self-consumption or for commercial use electricity generation (without OIK) from wind energy were only issued to three private persons (0.0146 MW) and one farm (0.015 MW).

Due to the advantageous geographical position of Latvia on the shores of the Baltic Sea, the western part of the country is exposed to the influence of southwestern winds, which prevail in this region. The western territories of Latvia are covered with forest plains, 
and in the eastern part of the country there are hills up to $300 \mathrm{~m}$ high. Offshore wind flows have significant potential for wind energy for generating electricity.

Depending on the type, wind turbines (WTs) start operating at a wind speed of $2.5-3.0 \mathrm{~m} / \mathrm{s}$ and reach a maximum capacity of about $12-14 \mathrm{~m} / \mathrm{s}$. In case of very high winds, about $25 \mathrm{~m} / \mathrm{s}$, the wind turbines stop operation to avoid damage.

Wind turbines are connected to the grid using back-to-back systems (voltage source converters) that control the excitation system. This makes it possible to separate the mechanical and electrical rotor frequencies. Converters allow the control of active and reactive power and voltage. Depending on the WT manufacturer, frequency and voltage can be adjusted within different limits.

Wind turbines can be divided into two groups, according to the location of the turbine axis of rotation: either vertical or horizontal.

In most cases, the wind turbine generator is used to start an autonomous load or as a backup power source for the end user. WTs tend to be installed at a height of 10-25 m above the ground.

Using the results of a previous publication [38] about the evaluation and dissemination of wind energy potential in the territory of Latvia. Data on the average wind speed and wind energy density in relative units, for example, at station atVenspils-average wind speed $4.1 \mathrm{~m} / \mathrm{s}$, average cubic wind speed $5.4 \mathrm{~m} / \mathrm{s}$ and relative unit 1 ; respectively at Ainaži station- $3.8 \mathrm{~m} / \mathrm{s}, 4.7 \mathrm{~m} / \mathrm{s}, 0.66$; at Priekuli station- $-3.4 \mathrm{~m} / \mathrm{s}, 4.5 \mathrm{~m} / \mathrm{s}, 0.58$; at Saldus station- $3.0 \mathrm{~m} / \mathrm{s}, 3.9 \mathrm{~m} / \mathrm{s}, 0.58$; and at Daugavpils station $5-2.5 \mathrm{~m} / \mathrm{s}, 3.3 \mathrm{~m} / \mathrm{s}, 0.23$. Station it is observation stations of the Latvian National Hydrometeorological and Climatological Service of the Latvian Environment, Geology and Meteorology Centre.

According to the analysis of wind efficiency in Latvia [38], the most suitable region for the installation of low-power wind turbines in Latvia is the eastern coast of the Baltic Sea; the higher elevation in northeastern Latvia, as well as the western region and most of central Latvian territory, are also considered suitable regions. In the rest of the territory of Latvia, wind efficiency is lower-thus, the amount of electricity produced with low-power WT decreases.

The supply in the low-capacity WT market is generally very large, and the choice is therefore wide. The modern wind turbine will be designed to operate for $120 \mathrm{~K}$ hours over an estimated 20-year service life. This will be a turbine that will run about $66 \%$ of the time for two decades [39]. Normally, the electrical efficiency of WT is around $24 \%$. Operation and maintenance (O\&M) costs represent a significant share of a wind turbine's total annual costs. For a new turbine, O\&M costs can easily amount to $20-25 \%$ of the total offset costs per kWh generated during turbine operation. If the turbine is relatively new, the proportion may be as low as $10-15 \%$, but may increase to at least $20-35 \%$ by the end of the turbine's lifetime. As a result, O\&M costs are gaining more attention, as manufacturers seek to significantly reduce these costs by developing new turbine designs that require fewer regular maintenance visits and less turbine downtime [40].

The duration and intensity of sunlight depend on the season, weather conditions, and the geographic location of the country. The annual global solar radiation incident on horizontal surfaces in southern European regions can reach $2200 \mathrm{kWh} / \mathrm{m}^{2}$. In the northern Europe, the maximum value of solar radiation is $1100 \mathrm{kWh} / \mathrm{m}^{2}$ [2] (see Figure 1).

According to Figure 1, solar radiation energy in Latvia can be used for 1700-1900 h a year. In Latvia, with $1 \mathrm{~kW} \mathrm{PV}$, it is possible to produce an average of $900-1000 \mathrm{kWh}$ of electricity per year: in summer months about 130-140 kWh per month, and in winter months 5-25 kWh per month. It can be concluded that the use of solar energy in Latvia for electricity will pay off only with highly efficient technologies and at the lowest possible capital investments [33].

PV is offered on the Latvian market by several manufacturers. Before choosing the manufacturer, it is necessary to make sure that the PV complies with the distribution system operator's microgenerator connection requirements. The overview of electricity traders' offers shows the main electricity traders that also offer PV installation. Prosumers need to 
make sure that the electricians contracted by the PV dealer have the appropriate certification for the installation of the microgenerator. This is required to obtain a distribution system operator PV installation permit.

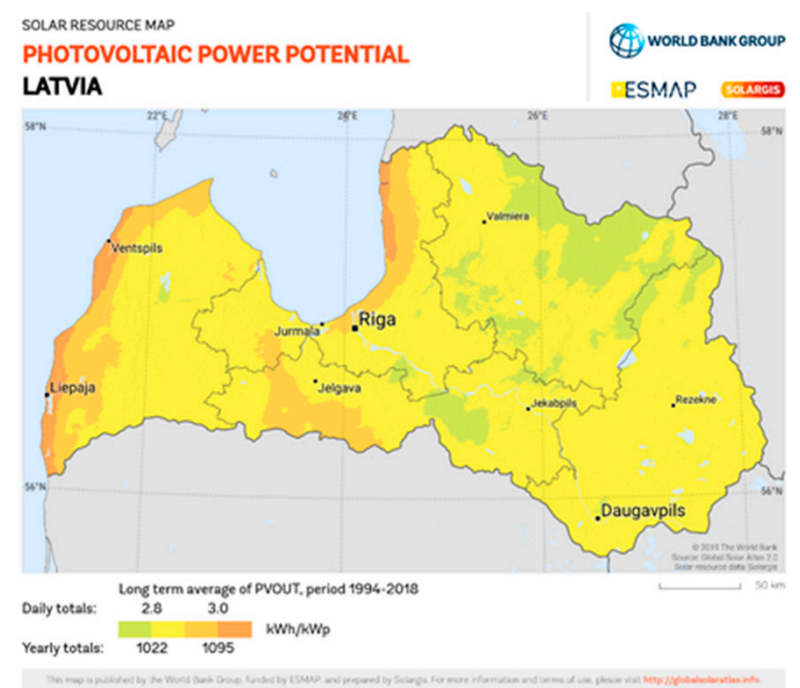

Figure 1. Photovoltaic (PV) power potential in Latvia [41].

In Latvia, PV installation is also offered by electricity traders, such as Enefit Ltd. (Tallinn, Estonia), JSC Latvenergo-Elektrum (Elektrum Solar) (Riga, Latvia), etc. Companies offer to support PV installation, including the development of consent, paperwork, PV delivery, and installation. Enefit and Elektrum have developed calculators where any interested person can calculate the required PV system with possible costs: https:/ /www. enefit.lv/en/majai/saules-paneli; https:/ / elektrumveikals.lv/en/home/elektrum-solar/ solar-guide (accessed on 19 March 2021).

The principal problems of solar and wind energies are the seasonal, daily, or instantaneous variations due to dependence on weather conditions, meaning the power generation is stochastic. It is needed to coordinate all connections to the network with operators, because solar and wind energy are unstable and change the voltage profile and frequency response of the system. This affects the transmission and distribution systems of the utility grid.

\subsection{Example of PV Installation in Latvia}

Of the Latvian households that have registered as electricity producers under the NET system, 98\% use solar energy. As mentioned above, the NET system is not applied to legal entities in Latvia. Based on our example of PV use, we want to determine the possibility of the participation of relatively large installations (on average, Latvian households install systems with a capacity of 5-6 kW) that can unite several households into cooperatives, and evaluate the possible benefit of using the network as storage (NET system), considering the price dynamics in the Nord Pool market.

For example, a real working PV installation was analyzed in order to get data on the real working parameters of the solar system in Latvian climatic conditions. The system consists of 350 panels (each panel power is $300 \mathrm{~W}$ ), 175 optimizers, and 3 inverters. The peak system peak power was $105 \mathrm{kWp}$, the installation angle was $30^{\circ}$, and the orientation was to the southeast (SE).

\section{Results and Discussion}

\subsection{Theoretical Justification of Consumer Introduction in Latvian Electricity Market}

In accordance with the Latvian National Energy and Climate Plan, the main energy planning documents have been developed up to 2030, and all calculations will be performed 
by 2030. After data analysis, taking into account the probability of electricity production in Latvia and applying the climatic correlation, the average amount of electricity production per year was assumed to be about $6.56 \mathrm{TWh} /$ year.

Public participation in energy production can also help achieve the goals set for Latvia, but this impact is currently small. Analysis of the data on the permits issued by the Ministry of Economics to increase the capacity of electricity production or to commission new production capacities has revealed the growth dynamics since 2016 to be an average of 100 connections of new electricity microgenerators per year. Using baseline data and a prospective extrapolation method, the number of potential new compounds was estimated to be about 1580 by 2030 . The study considered only the users of the NET system, since other households using microgenerators for their own consumption cannot be predicted-they do not use a common electrical grid to store electricity generated from renewable energy sources.

NET system prosumers installed system power is from $1 \mathrm{~kW}$ to $11 \mathrm{~kW}$, and the total installed capacity in March 2020 was $2800 \mathrm{~kW}$ [26]. The average power of RES technology is $5.4 \mathrm{~kW}$-in the calculations, its power is accepted as an assumption. In order to not reach the critical value of $3 \%$ (which would cause a need for network reconstruction) of the total generated electricity by prosumers, it was determined that by 2030 there should be about 40,300 prosumers connected to the electricity grid, which means that it would be necessary to connect about 4030 households each year. It can be noted that such an increase is difficult to achieve in Latvia, but still it is possible.

The impact of the NET system established in Latvia at the moment is small. Approximately 2 GWh/year of electricity is transferred to the network using the existing NET system, but this amount will not practically affect the expected energy consumption in 2020. It will constitute about $0.004 \%$ of the total electricity consumption [29].

Applying the accounting to all electricity produced by prosumers (in total electricity produced by prosumers, including direct consumption), the NET system participants' impact on energy consumption would increase by $30 \%$ of the total energy consumption in Latvia [33].

According to Latvia's National Energy and Climate Plan 2021-2030, the Latvian electricity transmission system is capable of accepting up to $800 \mathrm{MW}$ of additional capacity from new RE plants, which is about a third of all electrical capacities currently installed in Latvia. This is mainly the case for large energy producers (who will transmit electricity to the grid), but in terms of public involvement in the energy market, there is, of course, the potential to become a prosumer and use the network via the NET system as a storage. The biggest obstacle for public involvement in the energy market is the lack of support mechanisms and RES technologies that have a relatively high cost and long payback period.

Taking into account the fact that the majority of Latvians live in apartment buildings (74.2\% CSB data), there is great potential for prosumers if apartment owners become active consumers of electricity (to produce energy for self-consumption) by merging into apartment house associations/cooperatives and making energy communities.

The use of solar energy for electricity generation is one of the suitable options that could be realized in the case of households. However, it is important to note that many of the legal forms that could be used for the development of prosumers' energy community, such as cooperatives, Ltd. and etc., cannot currently use a NET system, as it is no longer a household but a legal entity. At the moment, the NET system is the only support mechanism in Latvia that can stimulate consumers to become prosumers.

In view of the provisions of the EU RES Directive [42], which stipulates that energy communities should receive the same support as households, it would be advisable to change the existing legislation framework in Latvia. The prosumers' energy community project is usually understood as a project for the generation of energy, using renewable energy sources for self-consumption and energy transmission to the grid, carried out by communities, such as residents' communities, cooperatives, apartment owners' associ- 
ations, several private house owners together or separately with the municipality, and private companies or other consumers.

Thus, the prosumers' energy community aims to reduce dependence on foreign fossil fuels, increase energy self-sufficiency, promote cooperation in smaller-scale energy networks, and increase shared democracy and social benefits. The energy community has a key role to play in the forthcoming energy transition, as we move from traditional, centralized energy systems to a more decentralized model. At present, the concept of energy communities is not clearly defined in Latvia, and so far, no such initiatives have been developed, and the establishment of such communities has not been specifically supported.

\subsection{Evaluation of Real PV System Electricity Production Versus Dynamic Electricity Price}

The use of solar energy is an environmentally friendly way to cover, for example, the electricity consumption of air conditioners in summer. Solar radiation has a direct interrelation with indoor microclimates; hence, the need for space cooling is at the same time when solar radiation intensity is increasing. The highest PV system efficiency is from March to August (see Figure 2). In the remaining months, about $10-15 \%$ of the total annual electricity production is generated. From October to February, the potential of solar energy is minimal, and cannot ensure the continuous sufficiency of electricity produced without an additional energy source.

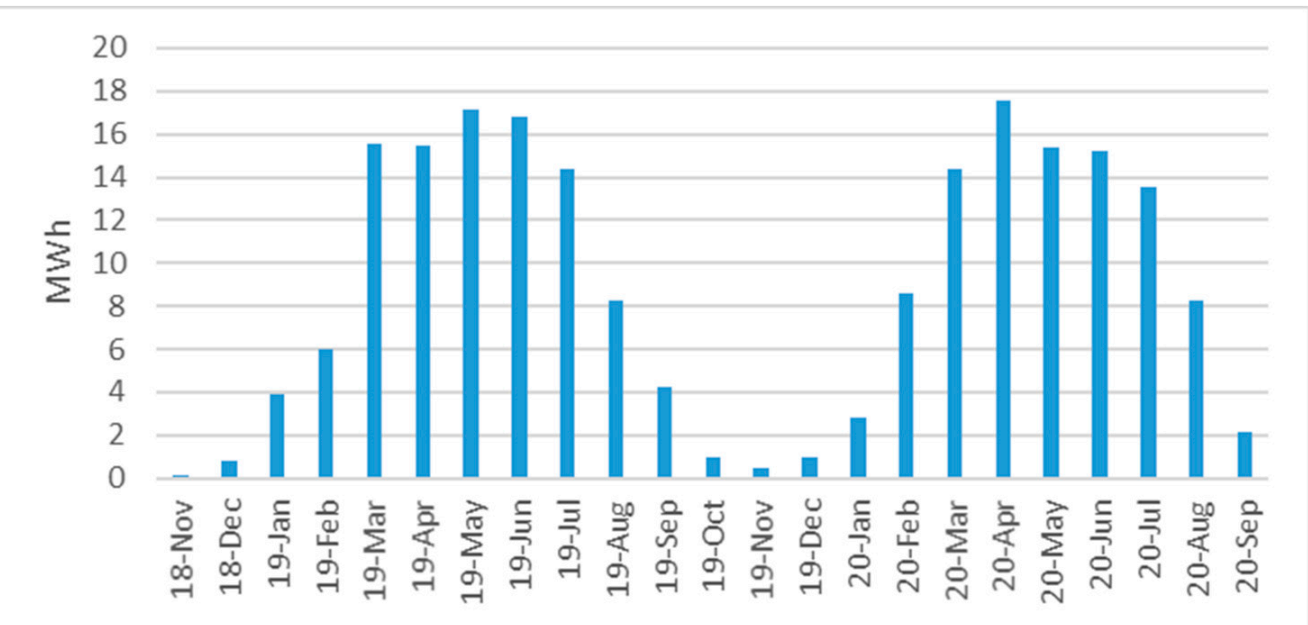

Figure 2. Real PV system electricity production capacity.

The study considered a real PV system, taking into account the possibility of evaluating the use of such a system to create an energy prosumers community. In this case, it is possible to connect up to 40 private houses or 3-4 standard five-story apartment buildings to the system. There are approximately 38,933 multi-apartment buildings in Latvia; the greatest portion of residential buildings is five-story buildings [43].

Figure 3 shows the average electricity power of a private house (data obtained from a smart meter) and the amount of electricity produced every hour by the PV system in one working day: 15 May 2019. The average monthly consumption of this house is 400-500 kWh.

The analysis of [44] shows that a PV system produces the largest amount of electricity when the consumption is low in the household. Therefore, the possibility for consumers to transfer excess electricity to the grid of neighbors should be considered. For balancing purposes, households and small commercial consumers can become prosumers, usually changing their electricity load profile depending, of course, on the amount of electricity produced, as well as on the optimization of consumption and the management of the demand side. Figure 4 shows an illustrative example of the prosumer load profile in the case of daily solar energy production. 


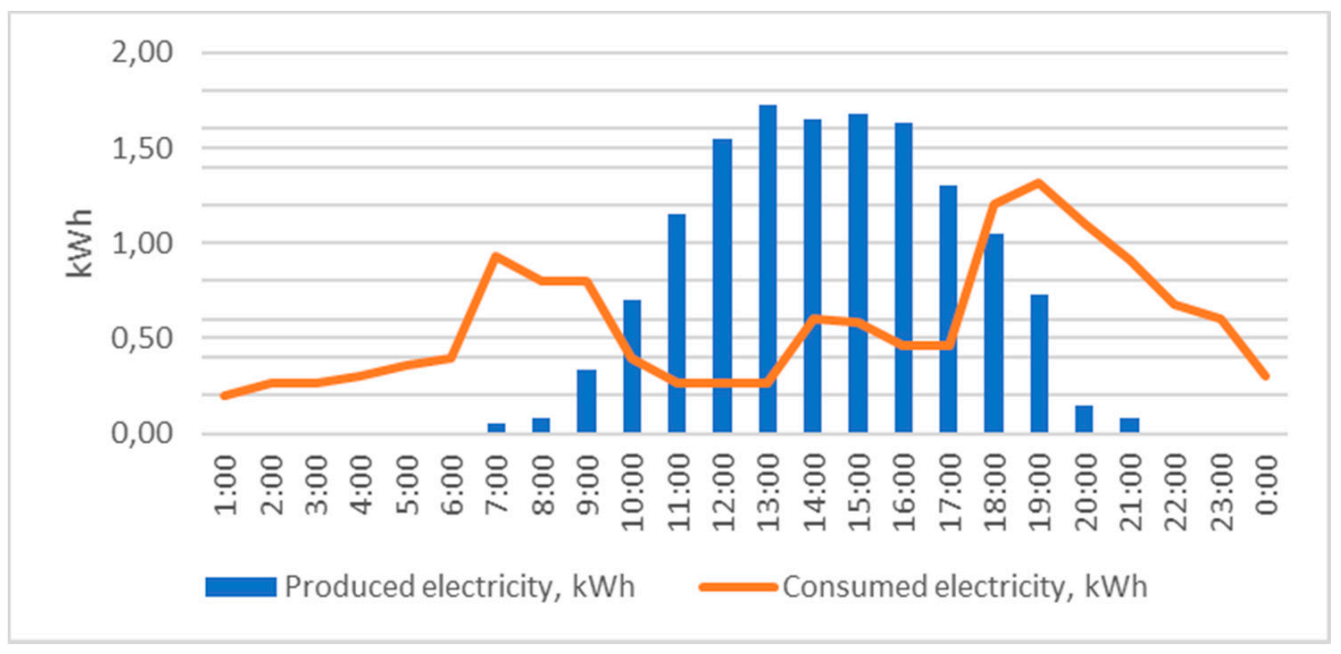

Figure 3. Average electricity power of a private house.

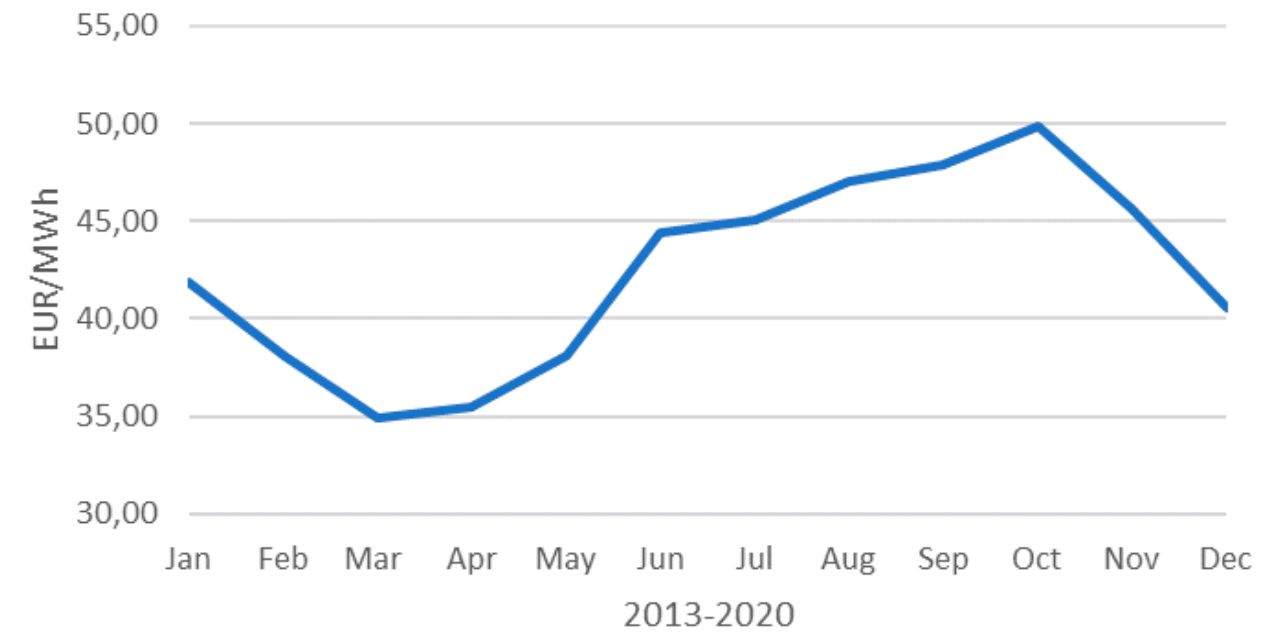

Figure 4. Dynamics of Nord Pool average Elspot prices.

In Latvia, the opening of the electricity market was implemented gradually in accordance with the Electricity Market Law. In 2007, the market was opened to merchants with a large amount of electricity consumption. Starting from 1 April 2012, electricity users with medium-high electricity consumption were involved in the market, and as of 1 November 2012, other merchants could also purchase electricity on the free market. From 1 January 2015, the market was opened to households. In the total electricity market consumption, the electricity consumption of merchants makes up $75 \%$, and $25 \%$ accounts to the electricity consumption of households [30]. Currently, one nominated electricity market operator (electricity exchange), which is Nord Pool, operates in Latvia. Nord Pool has average Elspot price data from July 2013 to September 2020, the analysis of which is shown in Figure 4.

Electricity prices are determined by various factors, such as fuel structure, cross-border interconnections, market interconnection, concentration of market suppliers, weather conditions, etc.

Figure 5 shows that in long term, average electricity prices during March-May are the lowest, while PV arrays work on maximal capacity. This specific should be taken into account during an economic analysis of investment in PV arrays. 


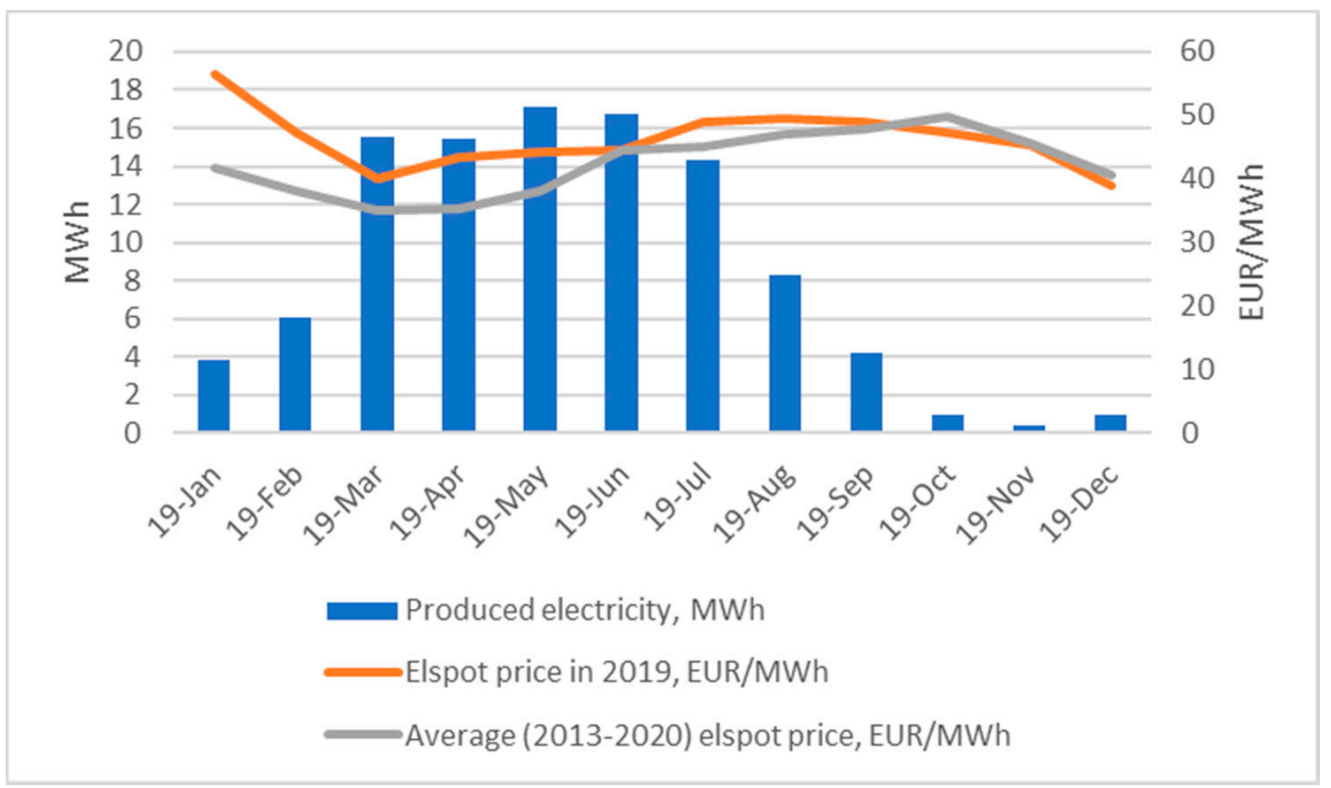

Figure 5. Real PV system electricity production versus dynamic electricity price.

\section{Conclusions}

Our study is limited across Latvian climatic conditions and similar countries, since it is directly related to RES use. The results of the study are highly dependent on the input data. In the course of this study, the main shortcomings were related to electricity consumption data unavailability from households and electricity production data using the NET system. Energy consumption/production data for the electricity trading market are protected by Article 19 of the Commercial Law; therefore, the calculations were based on publicly available, real historical data from the CSB of Latvia: annual energy balances, as well as annual reports of the distribution system operator ST, transmission system operator AST, Ministry of Environmental Protection, and Regional Development and Ministry of Economics of Latvia.

During the review of the current situation in Latvia, it was found that there are $573 \mathrm{mi}-$ crogenerator connections (up to $11.1 \mathrm{~kW}$ ) registered in Latvia. Their number will definitely increase, as electricity traders are also actively offering both solar panels and other electricity generating equipment. If the state starts subsidizing or providing support to small producers, the development dynamics of microgenerators will certainly be much higher.

In order to involve more citizens in the electricity market, it is essential to ensure an appropriate regulatory framework that will encourage such initiatives. Thus, for example, the NET system could also be applied to legal entities, considering the cost of providing the connection/cost of using the infrastructure. Also, in accordance with EU regulations, it is necessary to develop conditions to facilitate the procedures for prosumers working together (for example, residents of apartment buildings); it is also necessary to develop a regulation for renewable energy prosumer communities. Next, the inclusion of communities among the beneficiaries when developing different support mechanisms must be evaluated.

Analyzing the private household sector, there are strong chances that this sector will become a prosumer too, and this process depends only on the owner's opportunities. Private households can easily become prosumers by connecting a microgenerator and becoming a NET system user. In order to fully ensure the right of prosumers to sell surplus electricity, it is necessary to develop a balanced, peer-to-peer trading mechanism for various RES self-consumption groups, as well as to revise the conditions of the tax policy for operations with electricity outside the NET system.

An analysis of the real PV array has shown that the highest peak of production is achieved during March-June, while the electricity market price is the lowest. 
The next part of our project will focus on detailed analysis and simulation modeling of the implementation of prosumers in the energy market, with a high penetration of RES, as well as possible energy storage and profitable economic solutions for RES integration into the Latvian energy system.

Author Contributions: Conceptualization, K.L. and A.K.; methodology, A.T.; formal analysis, K.L., E.D.; investigation, K.L. and A.T.; writing — original draft preparation, K.L., A.K. and A.T.; writing-review and editing, K.L. and A.T.; visualization, E.D. All authors have read and agreed to the published version of the manuscript.

Funding: This research received no external funding.

Institutional Review Board Statement: Not applicable.

Informed Consent Statement: Not applicable.

Acknowledgments: In accordance with contract no. 1.2.1.1/18/A/001 between ETKC Ltd. and the Central Finance and Contracting Agency, the study is conducted by Lafivents Ltd. with support from the European Regional Development Fund (ERDF), within the framework of the project "Energy and Transportation Competence Centre".

Conflicts of Interest: The authors declare no conflict of interest. The funders had no role in the design of the study; in the collection, analyses, or interpretation of data; in the writing of the manuscript, or in the decision to publish the results.

\section{References}

1. Shao, M.; Han, Z.; Sun, J.; Xiao, C.; Zhang, S.; Zhao, Y. A review of multi-criteria decision making applications for renewable energy site selection. Renew. Energy 2020, 157, 377-403. [CrossRef]

2. Shipkovs, P.; Lebedeva, K.; Migla, L.; Kashkarova, G. Renewable energy resources effective use for rural development. Eng. Rural Dev. 2016, 2016, 481-487.

3. Borodinecs, A.; Bogdanovics, R.; Prozuments, A.; Tihana, J.; Gaujena, B. Evaluation of hybrid heating systems with a combination of fossil and renewable energy sources. IOP Conf. Ser. Earth Environ. Sci. 2019. [CrossRef]

4. Gielen, D.; Boshell, F.; Saygin, D.; Bazilian, M.D.; Wagner, N.; Gorini, R. The role of renewable energy in the global energy transformation. Energy Strateg. Rev. 2019, 24, 38-50. [CrossRef]

5. IRENA. Reaching Zero with Renewables: Eliminating $\mathrm{CO}_{2}$ Emissions from Industry and Transport in Line with the $1.5^{\circ} \mathrm{C}$ Climate Goal; IRENA: Abu Dhabi, United Arab Emirates, 2020; ISBN 978-92-9260-269-7.

6. Mohammadi, M.; Noorollahi, Y.; Mohammadi-ivatloo, B.; Hosseinzadeh, M.; Yousefi, H.; Khorasani, S.T. Optimal management of energy hubs and smart energy hubs-A review. Renew. Sustain. Energy Rev. 2018, 89, 33-50. [CrossRef]

7. Güner, S.; Erenoğlu, A.K.; Şengör, İ.; Erdinç, O.; Catalão, J.P. Effects of on-site pv generation and residential demand response on distribution system reliability. Appl. Sci. 2020, 10, 7062. [CrossRef]

8. Eurostat: Renewable Energy Statistics. Available online: https://ec.europa.eu/eurostat/statistics-explained/index.php/Renewable energy_statistics\#Share_of_renewable_energy_more_than_doubled_between_2004_and_2019 (accessed on 18 March 2021).

9. Wierling, A.; Schwanitz, V.J.; Zeiß, J.P.; Bout, C.; Candelise, C.; Gilcrease, W.; Gregg, J.S. Statistical Evidence on the Role of Energy Cooperatives for the Energy Transition in European Countries. Sustainability 2018, 10, 3339. [CrossRef]

10. Kampman, B.E.; Blommerde, J.; Afman, M.R. The potential of energy citizens in the European Union. Ce Delft 2016. Available online: https:// www.cedelft.eu/en/search?q=The+potential+of+energy+citizens+in+the+European+Union.++ (accessed on 17 November 2020).

11. Du, H.; Huang, P.; Jones, P. Modular facade retrofit with renewable energy technologies: The definition and current status in Europe. Energy Build. 2019, 205, 109543. [CrossRef]

12. Chung, K.-H.; Hur, D. Towards the Design of P2P Energy Trading Scheme Based on Optimal Energy Scheduling for Prosumers. Energies 2020, 13, 5177. [CrossRef]

13. European Economic and Social Committee; Pietkiewicz, J. Prosumer Energy and Prosumer Power Cooperatives: Opportunities and Challenges in the EU Countries (Own-Initiative Opinion); European Economic and Social Committee: Bruxelles, Belgium, 2016; pp. $44-52$.

14. Šajn, N. Electricity "Prosumers". Eur. Parlam. Res. Serv. 2016, 518-593, 1-10.

15. Inês, C.; Guilherme, P.L.; Esther, M.G.; Swantje, G.; Stephen, H.; Lars, H. Regulatory challenges and opportunities for collective renewable energy prosumers in the EU. Energy Policy 2020, 138, 111212. [CrossRef]

16. Kusakana, K. Optimal peer-to-peer energy management between grid-connected prosumers with battery storage and photovoltaic systems. J. Energy Storage 2020, 34, 101717. [CrossRef]

17. Kumar, N.M.; Ghosh, A.; Chopra, S.S. Power resilience enhancement of a residential electricity user using photovoltaics and a battery energy storage system under uncertainty conditions. Energies 2020, 13, 4193. [CrossRef] 
18. Khamis, A.; Khatib, T.; Amira Haziqah Mohd Yosliza, N.; Azmi, A.N. Optimal selection of renewable energy installation site in remote areas using segmentation and regional technique: A case study of Sarawak, Malaysia. Sustain. Energy Technol. Assess. 2020, 42, 100858. [CrossRef]

19. European Commission: Energy. Latvian Ministry of Economics: Latvia's National Energy and Climate Plan 2021-2030. Available online: https:/ / ec.europa.eu/energy/sites/ener/files/documents/ec_courtesy_translation_lv_necp.pdf (accessed on 5 January 2021).

20. Strupeit, L.; Palm, A. Overcoming barriers to renewable energy diffusion: Business models for customer-sited solar photovoltaics in Japan, Germany and the United States. J. Clean. Prod. 2016, 123, 124-136. [CrossRef]

21. Barbu, M.; Darie, G.; Siroux, M. Analysis of a residential photovoltaic-thermal (PVT) system in two similar climate conditions. Energies 2019, 12, 3595. [CrossRef]

22. Barone, G.; Buonomano, A.; Forzano, C.; Giuzio, G.F.; Palombo, A. Increasing self-consumption of renewable energy through the Building to Vehicle to Building approach applied to multiple users connected in a virtual micro-grid. Renew. Energy 2020, 159, 1165-1176. [CrossRef]

23. Schelly, C.; Prehoda, E.; Price, J.; Delach, A.; Thapaliya, R. Ratepayer Perspectives on Mid- to Large-Scale Solar Development on Long Island, NY: Lessons for Reducing Siting Conflict through Supported Development Types. Energies 2020, 13, 5628. [CrossRef]

24. Bogdanovičs, R.; Borodinecs, A.; Zajacs, A.; Šteinerte, K. Review of Heat Pumps Application Potential in Cold Climate. Adv. Intell. Syst. Comput. 2018, 543-554. [CrossRef]

25. Migla, L.; Snegirjovs, A.; Shutenkova, O. Performance analysis of solar assisted ground coupled heat pump system in Latvia. E3S Web Conf. 2020. [CrossRef]

26. Latvian Ministry of Economics: Permits for the Introduction of New Electricity Generation Facilities. Available online: https:/ /www.em. gov.lv/lv/nozares_politika/atjaunojama_energija_un_kogeneracija/atlaujas_jaunu_elektroenergijas_razosanas_iekartu_ieviesanai/ (accessed on 5 January 2021).

27. Latvenergo Group: Facts. Available online: https:/ /latvenergo.lv/en/par-mums/razosana (accessed on 18 March 2021).

28. Central Statistical Bureau of Latvia: Electricity Production, Imports, Exports and Consumption. Available online: https: //stat.gov.lv/en/statistics-themes/business-sectors/energy (accessed on 18 March 2021).

29. Central Statistical Bureau of Latvia: Statistical Tables. Available online: https://www.csb.gov.lv/en/statistics/statistics-bytheme/environment-energy / energy (accessed on 5 January 2021).

30. Sadales tīkls: Annual Reports. Available online: https://www.sadalestikls.lv/en/about-us-2/reports-and-indicators/annualreports/ (accessed on 5 January 2021).

31. Augstsprieguma Tikls AST: Latvian Electricity Market Overview. Available online: https://www.ast.lv/en/electricity-marketreview? year $=2019 \&$ month $=13$ (accessed on 5 January 2021).

32. Ministry of Environmental Protection and Regional Development of the Republic of Latvia: Ministry of Environmental Protection and Regional Development of the Republic of Latvia. Available online: https:/ / www.varam.gov.lv/ (accessed on 5 January 2021).

33. Latvian Ministry of Economics: Complex Measures for Improving the NET System of Electricity. 2019. Available online: https:/ / www.em.gov.lv/files/nozares_politika/ELIS_NETO_10.08.2018_nodevums.pdf (accessed on 10 December 2020).

34. Latvian Ministry of Economics: Facilitated Conditions for Net System Users. Available online: https://www.mk.gov.lv/lv/ aktualitates / atviegloti-nosacijumi-neto-sistemas-lietotajiem (accessed on 20 November 2020). (In Latvian)

35. Saeima: Electricity Market Law. Available online: https://likumi.lv/ta/en/en/id/108834 (accessed on 5 January 2021).

36. Public Utilities Commission: Regulations for a System Connection for Participants of an Electricity System. Available online: https://likumi.lv/ta/en/en/id/298067-regulations-for-a-system-connection-for-participants-of-an-electricity-system (accessed on 20 January 2021).

37. Sami, S. Modeling and Simulation of a Novel Combined Solar Photovoltaic-Thermal Panel and Heat Pump Hybrid System. Clean Technol. 2019, 1, 7. [CrossRef]

38. Upnere, S.; Bezrukovs, V.; Bezrukovs, V.I.; Jekabsons, N.; Gulbe, L. Computational Fluid Dynamics Methods for Wind Resources Assessment. Lecture Notes in Computer Science (including subseries Lecture Notes in Artificial Intelligence and Lecture Notes in Bioinformatics). LNCS 2020, 11974, 495-502.

39. Wind Measurement International. Available online: http://www.windmeasurementinternational.com/wind-turbines/omturbines.php (accessed on 19 March 2021).

40. Wind Energy the Facts. Available online: https://www.wind-energy-the-facts.org/operation-and-maintenance-costs-of-windgenerated-power.html (accessed on 19 March 2021).

41. PV Power Potential in Latvia. Available online: https://solargis.com/maps-and-gis-data/download/latvia (accessed on 19 March 2021).

42. The European Parliament and the Council of the European Union: Directive (Eu) 2018/2001 of the European Parliament and of the Council of 11 December 2018 on the promotion of the use of energy from renewable sources (recast) (Text with EEA relevance). Off. J. Eur. Union 2018, 328, 82-209.

43. Borodinecs, A.; Zemitis, J.; Sorokins, J.; Baranova, D.V.; Sovetnikov, D.O. Renovation need for apartment buildings in Latvia. Mag. Civ. Eng. 2016. [CrossRef]

44. Energy Community: Distributed Generation for Selfconsumption Key Aspects and Recommendations of Good Practice. Available online: https://www.energy-community.org/WSEL052017_Muratovi_recommendations\%20(4).pdf (accessed on 20 January 2021). 